\title{
PENGUNGKAPAN SOSIAL, DIVERSIFIKASI PERUSAHAAN, DAN KOMPENSASI BONUS TERHADAP MANAJEMEN LABA PADA PERUSAHAAN MANUFAKTUR DI BEI
}

\author{
Dwi Ermayanti \\ STIE PGRI Dewantara Jombang \\ Email:dwi_ermayanti@yahoo.co.id
}

\begin{abstract}
This study aims to determine the effect of Social Disclosure, Corporate Diversification and Compensation Bonuses both together (simultaneous) or individually (Partial) against the Earnings Management in Manufacturing Companies listed on the Indonesia Stock Exchange in 2012-2014. The data in this research is secondary data obtained from the financial statements and the Annual Report of companies in Indonesia Stock Exchange (IDX). The population in this research is manufacturing companies listed in Indonesia Stock Exchange in the year 2012-2014 as many as 141 each year with sampling purposive sampling and obtained a sample of 33 companies each year. Methods of data analysis used in this study were using multiple linear regression analysis to test hypotheses using SPSS version 16. The results showed that not all independent variables used in this study had a significant influence on Earnings Management.
\end{abstract}

Abstrak: Penelitian ini bertujuan untuk mengetahui pengaruh Pengungkapan Sosial, Diversifikasi Perusahaan dan Kompensasi Bonus baik secara bersama sama (Simultan) maupun individu (Parsial) terhadap terhadap Manajemen Laba pada perusahaan Manufaktur yang terdaftar di Bursa Efek Indonesia tahun 2012-2014. Data dalam penelitian ini merupakan data sekunder yang diperoleh dari laporan keuangan dan Laporan Tahunan perusahaan dalam Indonesia Stock Exchange (IDX). Populasi dalam peneltian ini yaitu perusahaan Manufaktur yang terdaftar di Bursa Efek Indonesia pada tahun 20122014 yaitu sebanyak 141 tiap tahunnya dengan pengambilan sampel secara purposive sampling dan diperoleh sampel sebanyak 33 perusahaan tiap tahunnya. Metode analisis data yang digunakan dalam penelitian ini adalah menggunakan analisis regresi linier berganda guna menguji hipotesis yang ada dengan menggunakan program SPSS versi 16. Dari hasil penelitian menunjukkan bahwa tidak semua variabel bebas yang digunakan dalam penelitian ini memiliki pengaruh signifikan terhadap Manajemen Laba.

Kata kunci: Manajemen Laba, Pengungkapan Sosial, Diversifikasi perusahaan dan Kompensasi Bonus

\section{PENDAHULUAN}

Dewasa ini manajemen laba telah menjadi perhatian bagi para praktisi dan akademisi di bidang manajemen serta akuntansi. Manajemen laba mulai menarik perhatian para peneliti karena manajemen laba sering dihubungkan dengan perilaku manajer atau para pembuat laporan keuangan dalam suatu perusahaan. Semakin merebaknya aktivitas manajemen laba telah mendorong berkembangnya perhatian publik pada pengungkapan informasi yang akurat. Oleh karena itu sebagai bentuk pertahanan terhadap resiko-resiko yang dapat 
merusak reputasi perusahaan, maka perusahaan akan berusaha meyakinkan stakeholder dengan melakukan pengungkapan pertanggung jawaban sosial.

Manajemen laba menurut Sulistyanto,(2008), adalah suatu usaha yang dilakukan oleh manajer perusahaan yang mempunyai kecenderungan untuk melakukan tindakantindakan yang dapat membuat suatu laporan keuangan menjadi baik. Laporan keuangan yang fungsi asal nya sebagai sumber informasi utama bagi stakeholder dimanfaatkan oleh para manajer untuk memberikan informasi yang menyesatkan kepada mereka, hal ini dilakukan oleh manajer dengan berbagai tujuan diantaranya untuk mengurangi beban pajak,menarik para investor agar menginvestasikan dananya ke perusahaan yang di jalankannya dan lain-lain.

Manajemen laba dapat dengan mudah dilakukan oleh para manajer ketika peraturan yang ditetapkan oleh pemerintah itu berubah-ubah seperti yang terjadi ketika pemerintah mengeluarkan UU No. 36 tahun 2008 yang menggantikan UU sebelumnya. Pajak menurut pasal 1 angka 1 UU No.6 tahun 1983 sebagaimana telah di sempurnakan terakhir dengan UU No. 28 tahun 2007 tentang ketentuan umum dan tata cara perpajakan adalah: "kontribusi wajib kepada negara yang terutang oleh orang pribadi atau badan yang bersifat memaksa berdasarkan UU. Dengan tidak mendapat timbalbalik secara langsung dan di gunakan untuk keperluan negara bagi sebesar-besarnya kemakmuran rakyat. Setelah UU tersebut diterbitkan banyak para manajer melakukan manajemen laba seperti yang telah dibuktikan oleh para peneliti-peneliti terdahulu.

Perubahan dalam tarif pajak penghasilan badan ini cukup dapat memberikan motivasi untuk melakukan rekayasa laba atau earning managemen (Ferdiansyah, 2011). Salah satu usaha yang dilakukan oleh para manajer untuk memperoleh keuntungan dari adanya perubahan tarif pajak badan ini adalah tax shifting yaitu dengan memindahkan laba tahun sebelum perubahan tarif pajak badan ke tahun sesudah perubahan tarif pajak, menurut akuntansi hal ini dapat diterima karena akuntansi menganut prinsip accrual basis yang pada dasarnya accrual basis ini digunakan untuk pengakuan pendapatan dan beban yang dilakukan pada periode dimana seharusnya pendapatan dan beban tersebut terjadi tanpa memperhatikan waktu penerimaan atau pengeluaran kas dari pendapatan atau beban.

PSAK No. 1 (revisi 2012) paragraf 15 secara implisit menyarankan untuk mengungkapkan tanggung jawab akan masalah lingkungan dan sosial : "Entitas dapat pula menyajikan, terpisah dari laporan keuangan, laporan mengenai lingkungan hidup dan laporan nilai tambah, khususnya bagi industri dimana faktor lingkungan hidup memegang peranan penting dan bagi industri yang menganggap karyawan sebagai kelompok pengguna laporan keuangan yang memegang peranan penting. Laporan tambahan tersebut diluar ruanglingkup standar akuntansi keuangan”.

Pengungkapan sosial ini memberi banyak dampak positif terhadap perusahaan diantaranya memberikan image yang positif di benak masyarakat,Media,dan juga stakeholder dalam menjalankan tanggungjawab sosial yang secara langsung hal ini akan berdampak pada keberlangsungan hidup usaha yang di jalankan,terutama pengungkapan sosial ini juga dapat meningkatkan laba perusahaan.

Selain pengungkapan sosial, ada banyak hal yang harus di perhatikan dalam manajemen laba salah satunya ialah yang ingin di teliti saat ini yaitu Diversifikasi Perusahaan dan Kompensasi Bonus. Berdasar teori agensi semua individu akan bertindak untuk kepentingannya sendiri (ditinjau dari tujuan maupun preferensi terhadap risiko). Manajemen sebagai agen bisa melakukan tindakan yang tidak menguntungkan pemilik atau prinsipal secara keseluruhan yang dalam jangka panjang bisa merugikan kepentingan 
dariperusahaan tersebut. Pemilik perusahaan memberikan wewenang pada pengelola dana dan mengambil keputusan perusahaan lainnya atas nama pemilik. Dengan we-wenang yang dimiliki ini, mungkin saja pengelola tidak bertindak yang terbaik untuk kepentingan pemilik, karena adanya perbedaan kepentingan. Keleluasaan dalampengelolaan perusahaan dapat menimbulkan penyalahgunaan wewenang. Kemungkinan terjadi bahaya moral (moral hazard) karena adanya asimetri informasi (agen memiliki informasi lebih banyak daripada prinsipal).

Berdasarkan latar belakang masalah yang telah dikemukakan maka dapat dirumuskan masalahnya sebagai berikut: (1) Apakah pengungkapan sosial berpengaruh terhadap manajemen laba pada perusahaan manufaktur di Indonesia?; (2) Apakah diversifikasi perusahaan berpengaruh terhadap manajemen laba pada perusahaan manufaktur di Indonesia?; (3) Apakah kompensasi bonus berpengaruh terhadap manajemen laba pada perusahaan manufaktur di Indonesia?; (4) Apakah pengungkapan sosial, diversifikasi perusahaan dan kompensasi bonus berpengaruh terhadap Manajemen Laba ada perusahaan manufaktur di Indonesia?

Batas Penelitian ini hanya pada sampel penelitian yang digunakan dalam penelitian ini adalah perusahaan yang bergerak di bidangmanufaktur yang terdaftar di Bursa Efek Indonesia (BEI) dalam rentang waktu 2012- 2014.Penelitian menggunakan laporan Keuangan dan laporan tahunan perusahaan yang dipublikasikan pada periode antara 20122014

Tabel 1. Penelitian Terdahulu

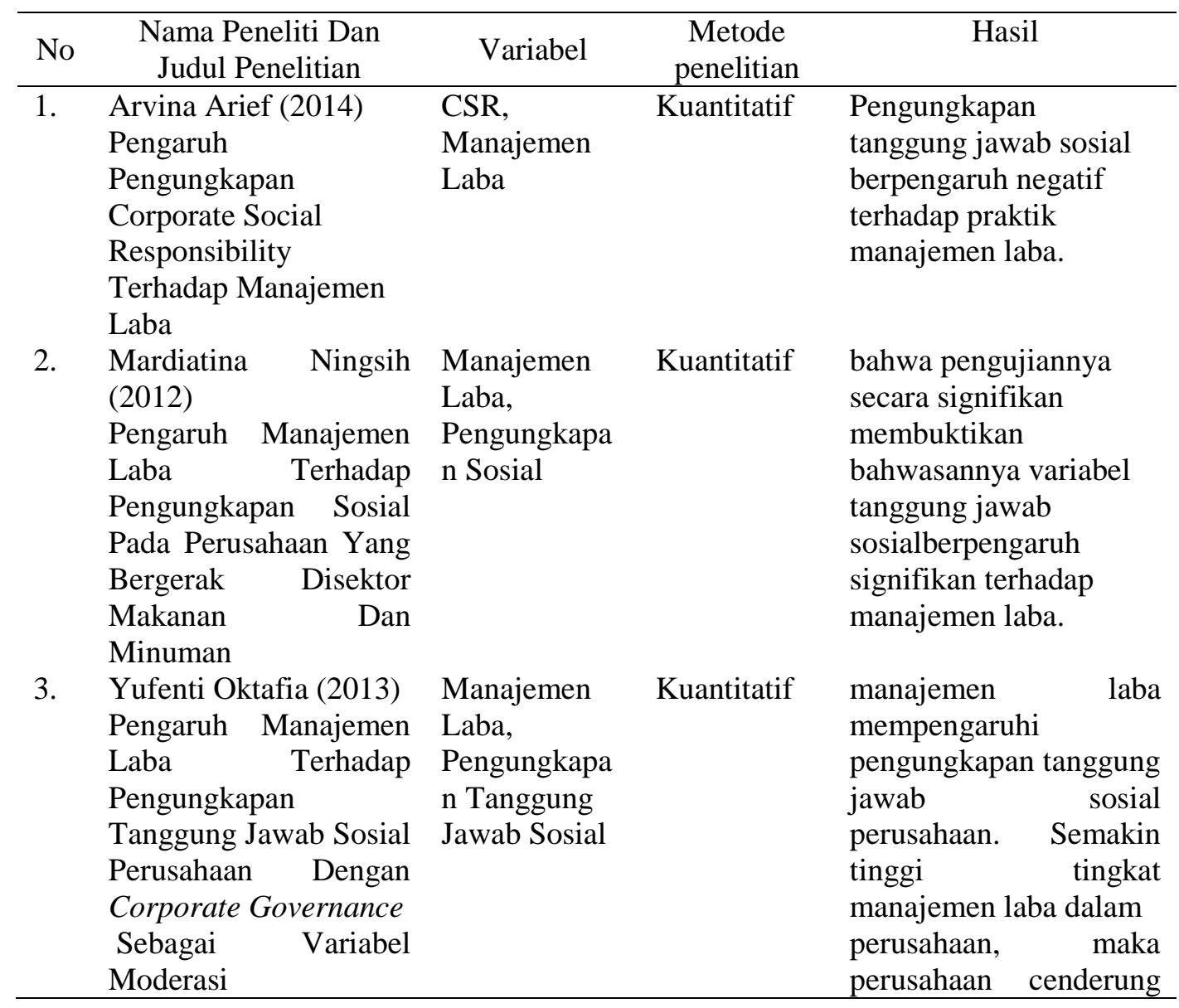


Ermayanti: Pengungkapan Sosial, Diversifikasi Perusahaan, dan Kompensasi....

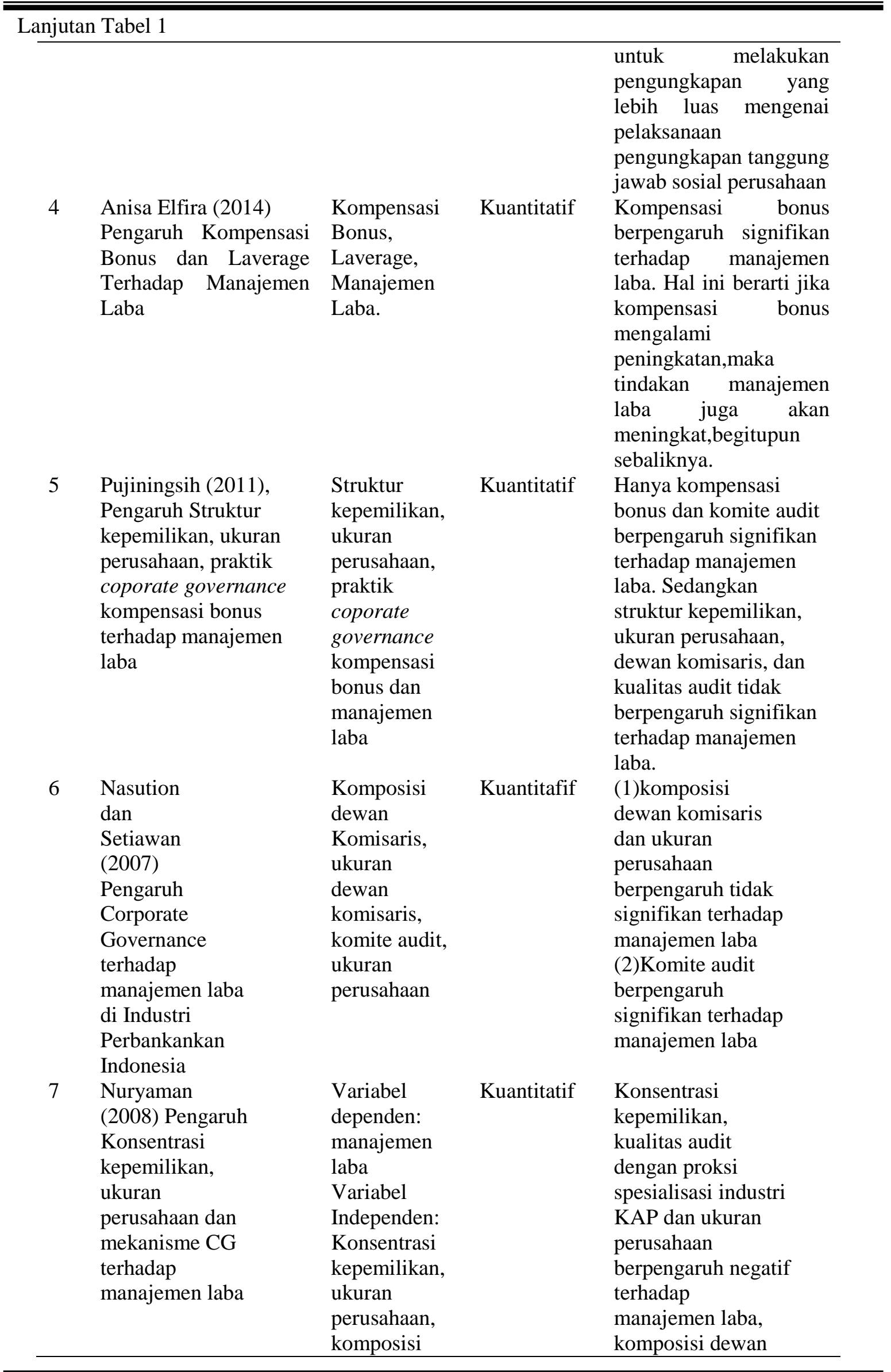


Ermayanti: Pengungkapan Sosial, Diversifikasi Perusahaan, dan Kompensasi....

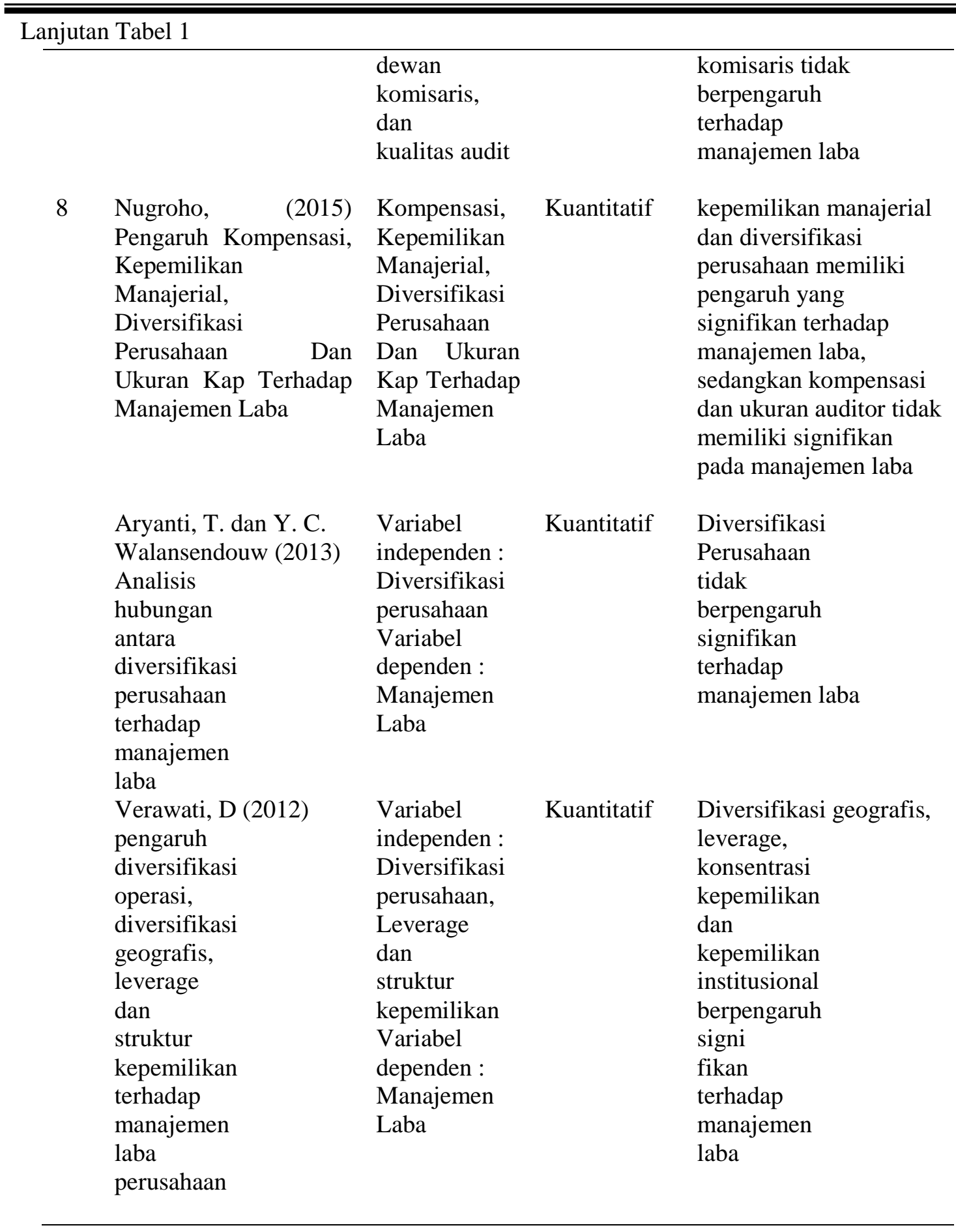

Teori Agensi. Timbulnya praktek manajemen laba dapat dijelaskan dengan teori agensi. Konsep teori agensi adalah hubungan atau kontrak antara prinsipal dan agen. Prinsipal mempekerjakan agen untuk melakukan tugas untuk kepentingan prinsipal, termasuk pendelegasian otorisasi pengambilan keputusan dari prinsipal kepada agen (Carolina (2014). Jika agen tidak berbuat sesuai kepentingan principal, maka akan terjadi konflik keagenan (agency conflict), sehingga memicu biaya keagenan (agency cost). Salah satu kendala yang akan muncul antara agen dan principal adalah adanya asimetris informasi. Asimetris informasi merupakan suatu keadaan dimana manajer memiliki akses informasi 
atas prospek perusahaan yang tidak dimiliki oleh pihak luar perusahaan (Rahmawati, dkk,2006).

Menurut Jensen dan Meckling (1976) teori agensi menggambarkan suatu hubungan yang timbul karena adanya kontrak yang ditetapkan antara principal yang menggunakan jasa agen untuk melaksanakan berbagai kepentingannya. Terdapat dua bentuk keagenan, yaitu hubungan antara manajer dan pemegang saham, serta hubungan antara manajer dengan pemberi pinjaman (bondholder). Dalam praktiknya, agar hubungan kontraktual dapat berjalan dengan baik, principal akan mendelegasikan otoritas dalam pengambilan keputusan kepada agen. Hubungann agensi muncul ketika satu orang atau lebih (prinsipal) mempekerjakan orang lain (agent) untuk memberikan suatu jasa dan kemudian mendelegasikan wewenang pengambilan keputusan kepada agent tersebut. Hubungan antar prinsipal dan agent dapat mengarah pada kondisi ketidak seimbangan informasi karena agent berada pada posisi yang memiliki informasi yang lebih banyak tentang perusahaan dibandingkan dengan prinsipal. Dengan asumsi bahwa individu-individu bertindak untuk memaksimalkan kepentingan diri sendiri, maka dengan informasi asimetri yang dimilikinya akan mendorong agen untuk menyembunyikan beberapa informasi yang tidak diketahui prisipal. Dalam kondisi yang asimetri tersebut, agen dapat mempengaruhi angka-angka akuntansi yang disajikan dalam laporan keuangan dengan cara melakukan manajemen laba.

Menurut Jensen dan Meckling (1976), terdapat tiga jenis utama dari biaya agensi, yaitu: (1) pengeluaran untuk memantau kegiatan manajerial, seperti biaya audit (audit fee); (2) pengeluaran untuk struktur organisasi dalam hal membatasi perilaku-perilaku manajerial yang tidak diinginkan, seperti penunjukan dewan direksi independen, restrukturisasi unit bisnis perusahaan, dan hierarki manajemen; (3) biaya kesempatan yang dapat terjadi ketika adanya pembatasan pada pemegang saham. Apabila pemegang saham tidak berupaya untuk mengontrol tindakan manajemen, mungkin pemegang saham dapat kehilangan sebagian kekayaan dikarenakan perilaku manajerial yang menyimpang.

Carolina (2014), solusi optimal untuk mengurangi konflik antara manajer dan pemegang saham adalah dengan kompensasi eksekutif yang didasarkan pada kinerja serta diikuti dengan beberapa tindakan pemantauan. Bukan hanya tindakan pemantauan yang diperlukan, tetapi juga beberapa mekanisme yang mendorong manajer untuk bertindak bukan berdasarkan kepentingan sendiri, melainkan kepentingan para pemegang saham.

Pengungkapan Sosial. Pengungkapan tanggung jawab sosial perusahaan merupakan proses pengkomunikasian dampak sosial dan lingkungan dari kegiatan ekonomi organisasi terhadap kelompok khusus yang berkepentingan dan terhadap masyarakat secara keseluruhan Ningsih (2012). Pengungkapan sosial adalah pengungkapan informasi tentang aktifitas perusahaan yang berhubungan dengan lingkungan sosial perusahaan. Pengungkapan sosial ini bertujuan untuk mengungkapkan aktifitas perusahaan yang berhubungan dengan lingkungan sosial untuk memberi nilai lebih kepada perusahaan,baik dari segi pencitraan masyarakat atau untuk tujuan laba.

Alasan Pengungkapan Sosial. Mardiatina Ningsih (2012), ada beberapa alasan yang mendukung konsep tanggung jawab sosial perusahaan. Adapun alasan-alasan yang dikemukakan oleh para pendukung tanggung jawab sosial yaitu: (1) Keterlibatan sosial merupakan respon terhadap keinginan dan harapan masyarakat terhadap peranan perusahaan. Dalam jangka panjang hal ini sangat menguntungkan perusahaan; (2) Keterlibatan sosial mungkin akan mempengaruhi perbaikan lingkungan masyarakat yang 
mungkin akan menurunkan biaya produksi; (3) Meningkatkan nama baik perusahaan, dan akan menimbulkan simpati klien, karyawan, investor dan lain-lain; (4) Menghindari campur tangan pemerintah dalam melindungi masyarakat. Karena campur tangan pemerintah dianggap cenderung akan membatasi peran perusahaan, sehingga jika perusahaan memiliki tanggung jawab sosial mungkin dapat menghindari pembatasan kegiatan perusahaan; (5) Dapat menunjukkan respon positif perusahaan terhadap norma dan nilai yang berlaku dalam masyarakat sehingga mendapat simpati masayarakat; (6) Sesuai dengan keinginan pemegang saham, dalam hal ini publik; (7) Membantu kepentingan nasional dan lingkungan seperti konservasi alam, pemeliharaan barang seni budaya, peningkatan pendidikan rakyat, lapangan kerja, dan lain-lain.

Menurut Diego (2007) mengungkapkan bahwa Pengungkapan informasi tentang perilaku perusahaan dan hasil tentang tanggung jawab sosial dapat membantu membangun citra positif di antara pemangku kepentingan.

Diversifikasi Perusahaan. Menurut Harto (2005) diversifikasi merupakan strategi pengembangan usaha melalui perluasan segmen bisnis maupun geografis, diversifikasi dapat dilakukan dengan membuka lini usaha baru, memperluas lini produk yang ada, memperluas wilayah pemasaran produk, membuka kantor cabang, melakukan merger, akuisisi dan lainnya. Strategi diversifikasi dipilih dan diterapkan oleh perusahaan ketika perusahaan berada dalam kondisi tertentu, yaitu ketika perusahaan merasakan profit dan pertumbuhan perusahaan mulai menurun pada industri utamanya, selain itu diversifikasi juga dilakukan dalam rangka memperkecil resiko investasi karena apabila perusahaan hanya melakukan bisnis pada sektor tunggal saja maka resiko investasinya cukup besar.

Ketika melakukan diversifikasi maka perusahaan akan menjadi perusahaan multi bisnis yang tidak hanya bergerak dalam satu lini bisnis saja, semakin beragam lini bisnis yang dimiliki perusahaan maka akan semakin banyak pula sumber pendapatan yang dimiliki perusahaan. Namun penerapan diversifikasi tidak hanya memberikan dampak positif bagi perusahaan tetapi menimbulkan beberapa biaya dari penerapan diversifikasi tersebut. Menurut El Mehdi dan Sebuoi (2011) diversifikasi dapat mengakibatkan beberapa masalah, yaitu: (1) Struktur organisasi yang terdapat dalam perusahaan menjadi lebih kompleks (2) Tingkat transparansi menjadi lebih rendah (3) Kompleksitas informasi bagi investor dan analisis keuangan menjadi semakin tinggi.

Jika di lihat dari perspektif teori keagenan, maka ketiga masalah tersebut dapat menyebabkan semakin tingginya asimetri informasi antara manajer dengan pemegang saham dan menciptakan keadaan yang mendukung bagi manajer untuk melakukan praktik manajemen laba.

Selain itu, Lupitasari (2012) juga berpendapat bahwa lini bisnis dari perusahaan yang terdiversifikasi yang tidak memberikan keuntungan dapat menimbulkan kerugian yang lebih besar jika dibandingkan dengan saat perusahaan tersebut bergerak pada satu lini bisnis saja. Harto (2005) yang menghubungkan teori keagenan dengan diversifikasi perusahaan menyatakan bahwa diversifikasi yang dilakukan perusahaan menjadi kurang optimal karena manajer yang melakukan diversifikasi cenderung untuk mengarahkan diversifikasi sesuai dengan kepentingannya.

Penelitian yang meneliti hubungan diversifikasi perusahaan dengan manajemen laba masih menunjukkan hasil yang tidak konsisten. Jiraporn et al. (2005) tidak menemukan adanya pengaruh antara diversifikasi perusahaan dengan manajemen laba. El Mehdi dan Sebuoi (2011) menemukan bahwa diversifikasi secara geografis berpengaruh 
positif terhadap manajemen laba dan diversifikasi secara industry berpengaruh negatif terhadap manajemen laba. Sedangkan Verawati (2012) menemukan adanya hubungan negative diversifikasi geografis terhadap manajemen laba namun tidak menemukan adanya pengaruh diversifikasi operasi terhadap manajemen laba. Untuk mengetahui level diversifikasi perusahaan, salah satu ukuran yang bisa digunakan adalah jumlah segmen usaha perusahaan. Jumlah segmen usaha ini dapat diketahui dari laporan keuangan yang dikeluarkan perusahaan.

Pelaporan segmen usaha mulai diwajibkan oleh Dewan Standar Akuntansi Keuangan melalui PSAK No. 05 Revisi 2009 mengenai segmen operasi (IAI, 2012). Sesuai dengan peraturan tersebut perusahaan yang memiliki berbagai segmen usaha dan geografis wajib melakukan pengungkapan jika masing-masing segmen memenuhi kriteria persyaratan penjualan, aktiva dan laba usaha (Verawati, 2012)

Kompensasi Bonus. Menurut Wibowo (2007) Kompensasi merupakan jumlah paket yang ditawarkan organisasi kepada pekerja sebagai imbalan atas penggunaan tenaga kerjanya.

Werther dan Davis (1996) Menyatakan kompensasi sebagai apa yang diterima pekerja sebagai tukaran atas kontribusinya kepada organisasi,Selanjutnya Werther dan Davis Menyatakan bahwa didalam komppensasi terdapat sistem insentif yang menghubungkan kompensasi dengan kinerja.

Elfira (2014), Kompensasi Bonus adalah semua pendapatan yang berbentuk uang, barang langsung atau tidak langsung yang diterima karyawan sebagai imbalan atas jasa yang diberikan kepada perusahaan.Kompensasi merupakan istilah yang berkaitan dengan imbalan-imbalan finansial (financial reward) yang diterima oleh orang-orang melalui hubungan kepegawaian mereka dengan sebuah organisasi. Pada umumnya bentuk kompensasi berupa finansial karena pengeluaran moneter yang dilakukan oleh organisasi. Kompensasi bisa langsung diberikan kepada karyawan, ataupun tidak langsung, dimana karyawan menerima kompensasi dalam bentuk-bentuk non moneter.

Dari berbagai pendapat diatas peneliti menyimpulkan bahwa Kompensasi Bonus adalah imbalan yang diiterima oleh para manajer atau karyawan terhadap apa yang telah mereka kerjakan kepada perusahaan. Dalam penelitian ini peneliti ingin mengetahui apakah manajemen laba mempengaruhi Kompensasi Bonus.

Manajemen Laba. Scott (2006) mendefinisikan earnings management sebagai pilihan kebijakan akuntansi oleh manajer sehingga dapat mencapai beberapa tujuan yang spesifik. Manajer dapat memilih beberapa kebijakan akuntansi untuk menghitung earnings tanpa melanggar GAAP (Generally Accepted Accounting Principle) (Prior et al., 2008) dalam Purwamitha (2011).

Scot (2000) membagi cara pemahaman atas manajemen laba menjadi dua. Pertama, melihatnya sebagai perilaku oportunistik manajer untuk memaksimumkan utilitasnya dalam menghadapi kontrak kompensasi, kontrak utang dan political costs. Kedua, dengan memandang manajemen laba dari perspektif efficient contracting (Efficient Earnings Management), dimana manajemen laba memberi manajer suatu fleksibilitas untuk melindungi diri mereka dan perusahaan dalam mengantisipasi kejadian-kejadian yang tak terduga untuk keuntungan pihak-pihak yang terlibat dalam kontrak. Dengan demikian, manajer dapat mempengaruhi nilai pasar saham perusahaannya melalui manajemen laba, misalnya dengan membuat perataan laba (income smoothing) dan pertumbuhan laba sepanjang waktu. Manajemen laba didefinisikan sebagai usaha manajer untuk melakukan 
manipulasi laporan keuangan dengan sengaja dalam batasan yang dibolehkan oleh prinsipprinsip akuntansi yang bertujuan untuk memberikan informasi yang menyesatkan kepada para pengguna laporan keuangan untuk kepentingan para manajer (Meutia, 2004).

Menurut Davidson, Stickney dan Weildalam Sulistyanto (2008) manajemen laba merupakan proses untuk mengambil langkahtertentu yang disengaja dalam batas-batas prinsip akuntansi yang diterima umum untuk menghasilkan tingkat yang diinginkan dari laba yang dilaporkan.

Schiper (2009:76) mendefinisikan manajemen laba adalah suatu intervensi yang disengaja dilakukan untuk memperoleh beberapa keuntungan pribadi pihak tertentu. Healy dan Wahlen dalam Sulistyanto (2006:32) menyatakan manajemen laba terjadi ketika para manajer menggunakan pertimbangan dalam pelaporan keuangan dan penyusunan transaksi untuk merubah laporan keuangan tentang kinerja ekonomik organisasi atau untuk mempengaruhi hasil sesuai dengan kontrak yang tergantung pada angka-angka akuntansi yang dilaporkan. Manajemen laba merupakan masalah keagenan yang seringkali dipicu oleh adanya pemisahan peran atau perbedaan kepentingan antara pemegang saham dengan manajemen perusahaan (Iqbal, 2007:41). Manajer melakukan manipulasi laba melalui manajemen laba agar laba nampak sebagaimana yang diharapkan.

Secara umum manajemen laba dilakukan oleh manajer untuk memberikan informasi yang menyesatkan kepada stakeholder teentang laporan keuangan yang disajikan dengan tujuan-tujuan tertentu. Manajemen laba adalah pemilihan kebijakan akuntansi tertentu oleh manajer untuk mencapai tujuan tertentu (Scott, 2007:45). Konsep manajemen laba ini sesuai dengan pendapat Davidson, Stickney, dan Weil dalam Sulistyanto (2006:61) yang menyatakan manajemen laba merupakan suatu proses pengambil langkah tertentu yang disengaja dalam batas prinsip akuntansi berterima umum untuk menghasilkan tingkat yang diinginkan dari laba yang dilaporkan. Definisi tersebut menunjukan manajemen laba sebagai aktivitas yang biasa dilakukan manajer dalam menyusun laporan keuangan

Tujuan manajemen adalah untuk memaksimalkan utilitas manajer dan meningkatkan nilai perusahaan. Tujuan ini mengacu pada motivasi-motivasinya yang meliputi: mendapatkan bonus yang tinggi, dana dalam kontrak hutang, kepercayaan publik dalam pasar modal, biaya pajak yang rendah, prestasi yang baik bagi CEO (Chief Executive Officer), dan reaksi positif dari investor dalam IPO (Initial Public Offering). Dengan adanya tujuan manajemen laba untuk memaksimalkan utilitas ini, aktivitas manajemen laba dapat digolongkan ke dalam paham etika utilitarianisme

Menurut Scott (1997: 352-364), ada beberapa faktor yang mendorong manajer melakukan praktik manajemen laba, yaitu: (1) Perencanaan Bonus. Faktor ini diungkapkan oleh Healy (1985), bahwa manajer yang memiliki informasi atas laba bersih perusahaan akan bertindak secara oportunistik untuk melakukan earning management dengan memaksimalkan laba saat ini; (2) Motivasi Lain. Faktor lain yang dapat mendorong manajer untuk melakukan manajemen laba adalah politik, pajak, pergantian CEO, IPO, dan pentingnya informasi kepada investor; (3) Motif Politik. Earning management digunakan untuk mengurangi laba yang dilaporkan pada perusahan publik. Perusahaan cenderung mengurangi laba yang dilaporkan karena adanya tekanan publik yang mengakibatkan pemerintah menetapkan peraturan yang lebih ketat; (4) Motif Pajak. Motivasi penghematan pajak menjadi motivasi earning management yang paling nyata. Berbagai metode akuntansi digunakan dengan tujuan penghematan pajak pendapatan; (5) Pergantian CEO. CEO yang mendekati masa pensiun akan cenderung menaikkan pendapatan untuk meningkatkan bonus mereka dan jika kinerja perusahaan buruk akan 
memaksimalkan pendapatan agar tidak diberhentikan; (6) IPO. Informasi mengenai laba menjadi sinyal atas nilai perusahaan pada perusahaan yang akan melakukan IPO. Hal ini berakibat bahwa manajer perusahaan yang akan go public melakukan earnings management menaikkan harga saham perusahaan; (7) Pentingnya Memberi Informasi Kepada Investor. Informasi mengenai kinerja perusahaan harus disampaikan kepada investor sehingga pelaporan laba perlu disajikan agar investor tetap menilai bahwa perusahaan tersebut dalam kinerja yang baik

Laporan Keuangan. Pengertian laporan keuangan menurut Kieso (2001) dalam buku nya yang di terjemahkan oleh Salim (2002) yang berjudul Akuntansi Intermediate adalah laporan keuangan merupakan sarana pengkomunikasian informasi keuangan utama kepada pihak-pihak diluar korporasi. Laporan ini menampilkan sejarah perusahaan yang di kuantifikasi dalam nilai moneter. Menurut Kieso (2001) Beberapa informasi keuangan hanya dapat atau lebih baik disajikan melalui Pelaporan Keuangan,Bukan melalui Laporan keuangan formal. Oleh karena itu dalam laporan keuangan diberikan catatan atas laporan keuangan atau pengungkapan atas laporan keuangan.

\section{Hipotesis}

H1 : Pengungkapan Sosial berpengaruh terhadap Manajemen Laba.

H2 : Diversifikasi Perusahaan berpengaruh terhadap Manajemen Laba.

H3 : Kompensasi Bonus berpengaruh terhadap Manajemen Laba

H4 : Pengungkapan Sosial, Diversifikasi Perusahaan dan Kompensasi Bonus Berpengaruh secara simultan terhadap Manajemen Laba.

Rancangan Penelitian. Menurut Given, (2008: 713), penelitian kuantitatif adalah pendekatan-pendekatan terhadap kajian empiris untuk mengumpulkan, menganalisa, dan menampilkan data dalam bentuk numerik daripada naratif. Pada penelitian ini peneliti menggunakan jenis penelitian kuantitatif karena penelitian kuantitatif merupakan salah satu jenis penelitian yang spesifikasinya sistemantis, terencana, dan terstruktur dengan jelas.

\section{METODE}

Populasi Dan Sampel. Populasi pada penelitian ini adalah perusahaan manufaktur yang terdaftar di Bursa Efek Indonesia (BEI) pada periode 2012-2014, perusahaan manufaktur yang terdaftar hingga akhir tahun 2014 adalah 141 perusahaan.

Sampel yang diambil pada penelitian ini adalah berupa laporan keuangan dan laporan tahunan yang diterbitkan oleh perusahaan yang bergerak dibidang manufaktur yang telah terdaftar pada Bursa Efek Indoonesia. Penelitian ini akan menggunakan metode Purposive Sampling, yaitu dengan cara memilih sampel saham perusahaan selama periode penelitian berdasar kriteria tertentu. Pada penelitian ini hanya menggunakan laporan keuangan dan laporan tahunan sebagai sumber utama informasi.

Adapun kriteria tertentu yang dipakai dalam pengambilan sampel adalah sebagai berikut: Perusahaan manufaktur yang terdaftar selama periode pengamatan dari tanggal 1 Januari 2012 s/d 31 Desember 2014, Memiliki data keuangan dan tahunan lengkap terutama tentang variabel yang di teliti selama tahun 2012-2014, Melaporkan laporan keuangan dalam rupiah per 31 Desember setiap tahunnya, Melaporkan salah satu dari variabel independen yaitu Pengungkapan Sosial dan Kompensasi Bonus selama periode 
2012-2014, Berdasarkan kriteria diatas maka jumlah sampel penelitian ini adalah sebanyak 33 perusahaan sampel selama 3 tahun dari 141 populasi yang ada.

Metode Pengumpulan Data. Metode pengumpulan data yang digunakan dalam penelitian ini adalah studi dokumentasi, dengan cara mengumpulkan data berupa laporan keuangan yang di publikasikan oleh perusahaan pada periode 2012-2014. Data tersebut diperoleh dari situs resmi Bursa Efek Indonesia, dengan alamat www.idx.co.id, data dari ICMD ( Indonesian Capital Market Dirrectory). Sedangkan study pustaka melalui artikel dan sumber data penelitian terdahulu yang berkaitan dengan informasi yang dibutuhkan.

Analisis Regresi Linear Berganda. Rumus matematis dari regresi berganda yang digunakan dalam penelitian ini adalah:

Manajemen Laba $(\mathrm{Y})=\mathbf{a}+\mathbf{b}_{\mathbf{1}}$ Pengungkapan Sosial $\left(\mathbf{X}_{\mathbf{1}}\right)+\mathbf{b}_{\mathbf{2}}$ Diversifikasi Perusahaan $\left(\mathrm{X}_{2}\right)+\mathbf{b}_{3}$ Kompensasi Bonus $\left(\mathrm{X}_{3}\right)+\boldsymbol{e}$

\section{HASIL DAN PEMBAHASAN}

Penelitian dilakukan dari periode 2012-2014 pada seluruh perusahaan manufaktur yang terdaftar di Bursa Efek Indonesia yang memenuhi kriteria di atas dengan pengumpulan data menggunakan metode Purposive Sampling dimana populasi di pilih untuk diteliti dan sesuai dengan obyek penelitian.

Tabel 2. Analisis Regresi Linier Berganda

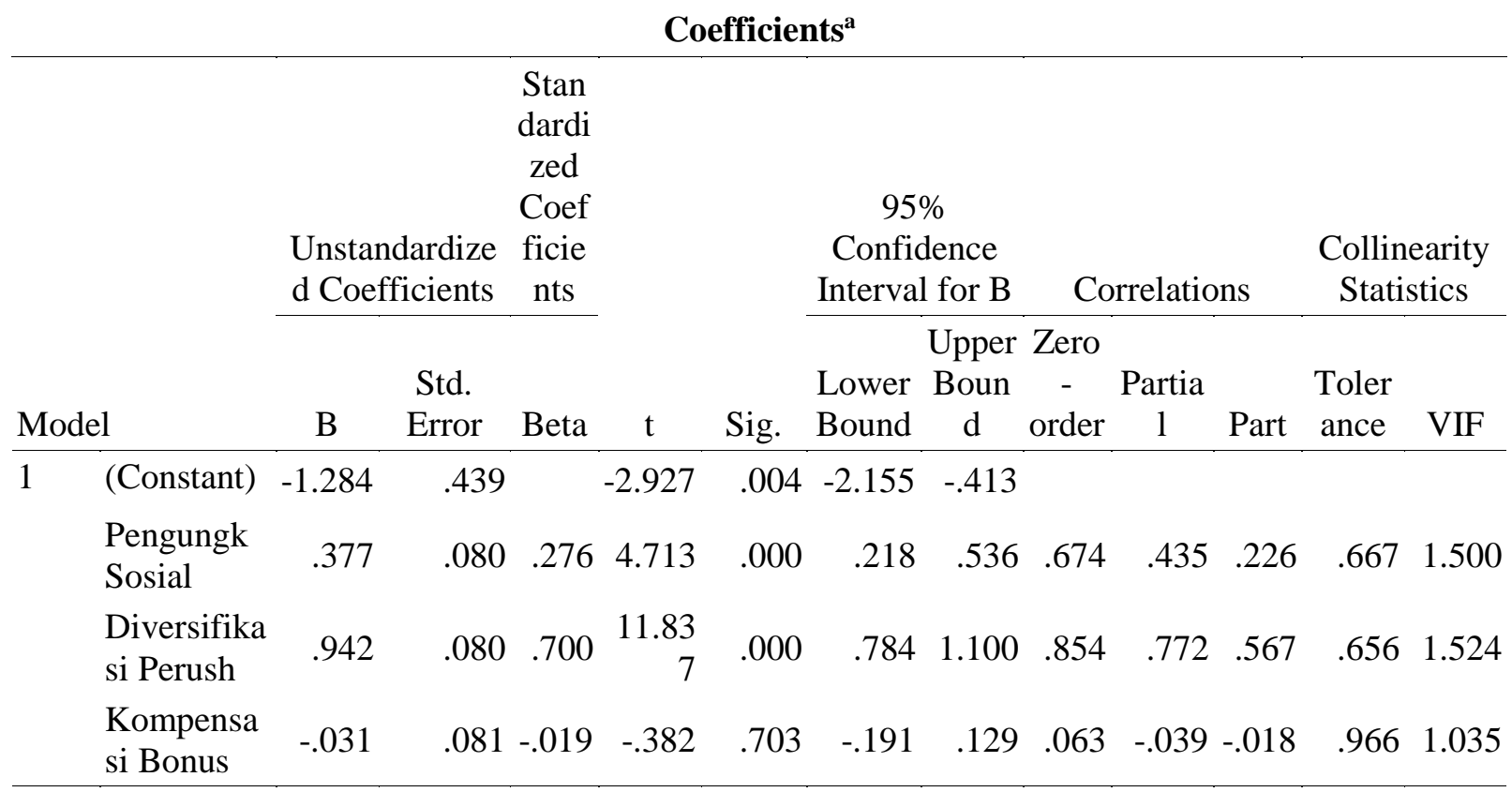

a. Dependent Variable: Manajemen Laba

Dari Tabel 2, secara keseluruhan dapat diperoleh persamaan regresi linier berganda sebagai berikut:

Manajemen Laba = - $7.267+$ 0,506 Pengungkapan Sosial+ 0,681 Kompensasi Bonus 
Koefisien Determinasi. Koefisien determinasi ( $\mathrm{R}$ Square) pada intinya mengukur seberapa jauh kemampuan model dalam menerangkan variasi variabel dependennya. Nilai Adjusted R Square yang mendekati satu berarti variabel variabel independennya memberikan hampir semua informasi yang dibutuhkan untuk memprediksi variasi variabel dependen. Hasil perhitungan koefisien determinasi penelitian ini dapat terlihat pada Tabel berikut ini:

Tabel 3. Model Summary ${ }^{\mathrm{b}}$

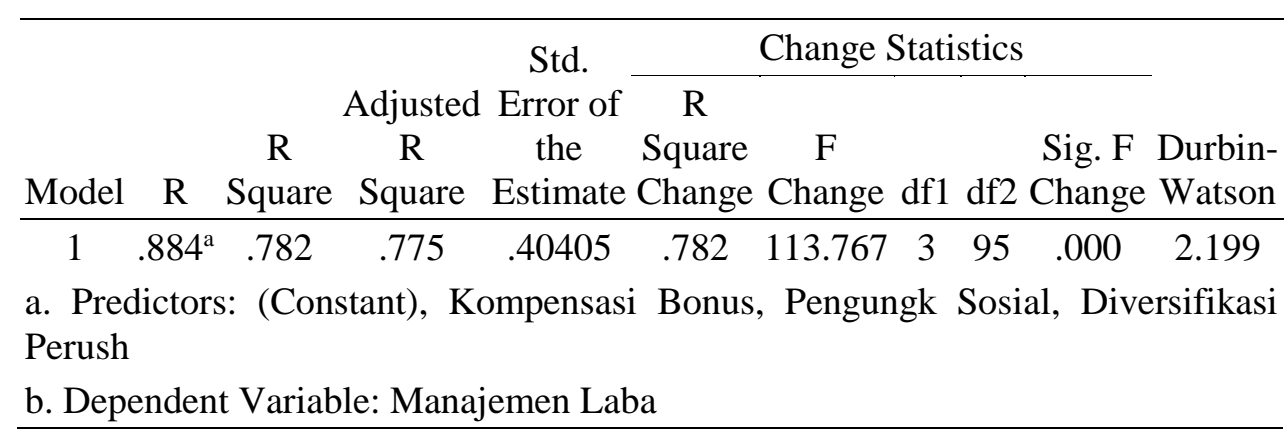

Dari hasil perhitungan diatas kolom menunjukan bahwa nilai koefisien determinan ( $\left.\mathrm{R}^{2}\right)$ sebesar 0,884 yang berarti 11,6\% , ini menunjukkan bahwa 88,4\% variabel Manajemen Laba dipengaruhi oleh variabel Pengungkapan Sosial, Diversifikasi Perusahaan dan Kompensasi Bonus secara bersama sama, sedangkan sisanya $11,6 \%$ dijelaskan oleh variabel lain yang tidak termasuk dalam penelitian ini.

Uji t. Hasil nilai signifikan dapat dilihat pada tabel berikut ini: (1) Hipotesis pertama dalam penelitian ini adalah Pengungkapan Sosial berpengaruh terhadap Manajemen Laba. Berdasarkan hasil uji-t, variabel perbaikan Pengungkapan sosial (X1) secara statistik memberikan pengaruh perubahan yang signifikan terhadap Manajemen Laba. Hal ini terbukti dari nilai t-hitung 4,713 memberikan nilai probabilitas sebesar 0,000 adalah lebih kecil dari nilai $\alpha=0,05$; (2) Hipotesis kedua hasil uji-t, variabel Diversifikasi perusahaan (X2) secara statistik memberikan pengaruh perubahan yang signifikan terhadap manajemen laba. Hal ini terbukti dari nilai t-hitung 11,837 memberikan nilai probabilitas sebesar 0,000 adalah lebih kecil dari nilai $\alpha=0,05$; (3) Hipotesis ketiga hasil uji-t, variabel kompensasi bonus (X3) secara statistik memberikan pengaruh perubahan yang tidak signifikan terhadap manajemen laba. Hal ini terbukti dari nilai t-hitung -0,382 memberikan nilai probabilitas sebesar 0,703 adalah lebih besar dari nilai $\alpha=0,05$.

Uji F. Pengujian hipotesis uji F digunakan untuk melihat apakah secara keseluruhan variabel bebas mempunyai pengaruh yang bermakna terhadap variabel terikat. Derajat kepercayaan yang digunakan adalah 5\% atau 0,05. Jika nilai sig lebih kecil dari derajat kepercayaan dan nilai $\mathrm{f}$ hitung < $\mathrm{f}$ tabel maka semua variabel bebas secara simultan berpengaruh terhadap variabel terikat. Dari hasil pengujian simultan diperoleh hasil seperti pada Tabel 4.

Berdasarkan Tabel 4 dapat diketahui bahwa nilai F hitung sebesar 113,767 dengan angka probabilitasnya sebesar 0,000 ( $\mathrm{p}<0,05)$. Nilai F-hitung sebesar 113,767 dengan probabilitas 0,000 menunjukkan bahwa persamaan regresi yang didapat, secara statistik terbukti mampu menjelaskan keragaman pengungkapan social, diversifikasi perusahaan 
dan kompensasi bonus. Hal tersebut dapat dibuktikan dengan nilai probabilitas kesalahan model sebesar 0,000 adalah lebih kecil dari nilai $\alpha=0,05$

Tabel 4. ANOVA ${ }^{\mathrm{b}}$

\begin{tabular}{llrrrrr}
\hline Model & Sum of Squares & df & Mean Square & F & \multicolumn{1}{c}{ Sig. } \\
\hline 1 & Regression & 55.721 & 3 & 18.574 & 113.767 & $.000^{\mathrm{a}}$ \\
& Residual & 15.510 & 95 & .163 & & \\
& Total & 71.231 & 98 & & & \\
\hline
\end{tabular}

a. Predictors: (Constant), Kompensasi Bonus, Pengungk Sosial, Diversifikasi Perush

b. Dependent Variable: Manajemen Laba

\section{PENUTUP}

Simpulan. (1) Pengungkapan Sosial tidak berpengaruh signifikan terhadap Manajemen Laba; (2) Diversifikasi perusahaan berpengaruh signifikan terhadap Manajemen Laba; (3) Kompensasi Bonus tidak berpengaruh signifikan terhadap Manajemen Laba; (4) Pengungkapan Sosial, Diversifikasi perusahaan dan Kompensasi Bonus berpengaruh secara simultan terhadap Manajemen Laba

Saran. Saran untuk penelitian ini selanjutnya diharapkan dapat melengkapi keterbatasan penelitian dengan mengembangkan beberapa hal sebagai berikut: (1) Membah kategori perusahaan yang dijadikan sampel; (2) Memperpanjang periode pengamatan, hendaknya pengamatan dilakukan lebih dari 3 tahun (3) Menambah variabel penelitian misal seperti ukuran perusahaan, profitabilitas, struktur kepemilikan dan lain sebagainya.

\section{DAFTAR RUJUKAN}

Adiasih, Priskila dan Indra Wijaya Kusuma. (2011) "Manajemen Laba Pada Saat Pergantian CEO (Dirut) Di Indonesia”. Jurnal Akuntansi dan Keuangan, 13 (2): 6779.

Chun, Hong-Min, (2014) "Corporate International Diversification and Corporate Social Responsibility: Evidence from Korean Firms, Asian Social Science”, 10 (21): 2014, ISSN 1911-2017 E-ISSN 1911-2025, Published by Canadian Center of Science and Education 54

Dan S. Dhaliwal, Suresh Radhakrishnan, Albert Tsang and Yong George Yang, (2012)

"Nonfinancial Disclosure and Analyst Forecast Accuracy: International Evidence on Corporate Social Responsibility Disclosure”, The Accounting Review, 87: 723 - 759. American Accounting Association DOI: 10.2308/accr-10218

Ekasari Narolita dan Komang Ayu Krisnadewi, (2016) "Pengaruh Penerapan Corporate Governance Pada Manajemen Laba Oleh Chief Executive Officer Baru”, ISSN: 2302-8556 E-Jurnal Akuntansi Universitas Udayana. 14 (1): 635-662

Elfira, Anisa, (2014) "Pengaruh Kompensasi Bonus dan Laverage Terhadap Manajemen Laba”, Jurnal Ekonomi Akuntansi, Padang.

Fauziah Fitri, (2015) "Pengaruh Kepemilikan Manajerial, Praktik Corporate Governance Dan Kompensasi Bonus Terhadap Pengelolaan Laba (Earnings Management) (Studi 
Empiris Pada Perusahaan Manufaktur yang Terdaftar di BEI Tahun 2009-2012)”, Skripsi Program Studi Akuntansi Fakultas Ekonomi Universitas Negeri Padang Goss, A., and G. Roberts. (2009) "The Impact of Corporate Social Responsibility on the Cost of Bank Loans”. Working paper, York University

Ghozali, Imam, (2005) Aplikasi Analisis Multivariate dengan Program SPSS, Edisi Ketiga, Badan Penerbit Universitas Diponegoro, Semarang.

Handhani Nazir, (2014) "Pengaruh Kepemilikan Institusional, Komposisi Dewan Komisaris Independen, Reputasi Kantor Akuntan Publik Dan Kompensasi Bonus Terhadap Manajemen Laba (Studi Empiris Pada Perusahaan Finance Yang Terdaftar Di Bei Tahun 2008-2011)”, Skripsi Universitas Negeri Padang

Ikatan Akuntan Indonesia, (2012) Standar Akuntansi Keuangan, IAI, Jakarta.

Jennifer Martı́nez-Ferrero, Shantanu Banerjee Isabel Marı'a Garc1'a-Sa'nchez, (2014) “Corporate Social Responsibility as a Strategic Shield Against, Costs of Earnings Management Practices, J Bus Ethics”, DOI 10.1007/s10551-014-2399-x, J Bus Ethics, Published in line : 19 September 2014

Kieso, E. Donal, Weygandt, J.J, Warfield, T.D, (2001) Intermediate Accounting. Erlangga. Jakarta.

I Gusti Ayu Putu Shita P. (2011) “Analisis Faktor - Faktor yang Berpengaruh terhadap Manajemen Laba (Studi pada Perusahaan Sektor Perbankan yang Terdaftar di BEI Tahun 2006 - 2008)”. Skripsi, Universitas Diponegoro Semarang

I Made Gede Agus Kusuma, (2014) "Pengaruh Konservatisme Terhadap Hubungan Employee Stock Option Plan Dengan Manajemen Laba”, ISSN: 2302-8556 E-Jurnal Akuntansi Universitas dayana 7 (2): 414-430

Intania Destiani Putri, Syuhada Sofyan, (2013) “Analisis Pengaruh Struktur Dan Mekanisme Good Corporate Governance, Ukuran Perusahaan Dan Leverage Terhadap Manajemen Laba”, Diponegoro journal Of management, http://ejournals1.undip.ac.id/index.php/dbr, 2 (2):1-16, ISSN: 2337-3792

Lasdi, Lodovicus. (2008) Perilaku Manajemen Laba Perusahaan dan Konservatisme Akuntansi: Berbeda atau Sama?, Jurnal Manajemen Teori dan Terapan. Tahun 1, No. 2.

Liu Jing Hui. (2012) "Board Monitoring, Management Contracting and Earnings Management: An Evidence from ASX Listed Companies”. International Journal of Economics and Finance, 4 (12): 121-136

Lopin Kuo, Chin Chen Yeh and Hui Cheng Yu, (2011) Disclosure of Corporate Social Responsibility and Environmental Management: Evidence from China, Corporate Social Responsibility and Environmental Management

Corp. Soc. Responsib. Environ. Mgmt. (2011) Published online in Wiley Online Library (wileyonlinelibrary.com) DOI: 10.1002/csr.274

Mehmet Ünsal Memiş, Emin Hüseyin Çetenak, (2012) "Earnings Management, Audit Quality and Legal Environment: An International Comparison”, International Journal of Economics and Financial Issues, 2 (4): 460-469, ISSN: 2146-4138, www.econjournals.com

Ningsih Mardiatina, (2012) "Pengaruh Manajemen Laba Terhadap Pengungkapan Sosial Pada Perusahaan Yang Bergerak Disektor Makanan Dan Minuman Yang Terdaftar Di Bursa Efek Indonesia (Bei)”, Jurnal Ekonomi dan Bisnis, Lampung.

Nazir Mohammad, (2013) Metode Penelitian, Ghalia Indonesia, Bogor. 
Nugroho Bhuono Agung, (2005) Strategi Jitu Memilih Metode Statistik Penelitian Dengan SPSS,Semarang.

Mehdi, Imen Khanchel El., Seboui, Souad. (2011) "Coporate diversification and earnings management”. Review of Accounting and Finance, 10 (2): 176-196

Palestin , Halima Shatila. (2008) “Analisis Pengaruh Struktur Kepemilikan, Praktik Corporate Governance Dan Kompensasi Bonus terhadap Manajemen Laba”. (Studi Empiris Di Bursa Efek Indonesia). Disertasi, Universitas Diponegoro

Poppy Indriani, Jaka Darmawan dan Siti Nurhawa, (2014) “Analisis manajemen laba terhadap nilai perusahaan yang Terdaftar di BURSA EFEK INDONESIA (Studi Khusus: Perusahaan Dagang Otomotif)”, Jurnal Akuntansi \& Keuangan, 5 (1): 1932

Pujiningsih, Andiany Indra. (2011) "Pengaruh Struktur Kepemilikan, Ukuran Perusahaan, Praktik Corporate Governance dan Kompensasi Bonus Terhadap Manajemen Laba (Studi Empiris Pada Perusahaan Manufaktur Yang Terdaftar di BEI Tahun 20072009)”. Skripsi Universitas Diponegoro: Semarang

Priantinah, Denies. (2009) "Manajemen Laba Ditinjau dari Sudut Pandang Oportunistik dan Efisiensi dalam Positive Accounting Theory”. Jurnal Pendidikan Akuntansi Indonesia, VII (1): 99-109

Oktafia Yufenti, (2013) "Pengaruh Manajemen Laba Terhadap Pengungkapan Tanggung Jawab Sosial Perusahaan Dengan Corporate Governance Sebagai Variabel Moderasi”, Jurnal Ilmiah Akuntansi Dan Humanika, Malang.

Rehobot, Tanomi, (2012) "Pengaruh Kompensasi Manajemen, Perjanjian Hutang dan Pajak Terhadap Laba pada Perusahaan Manufaktur di Indonesia”, Jurnal Ilmiah Mahasiswa Akuntansi, 1 (3), Mei

Rowland Bismark, Dionysia Kowanda, Muhammad Firdaus dan Rena Nurul Ummah, (2015) "Mekanisme Good Corporate Governance, Ukuran Perusahaan, Struktur Kepemilikan Manajerial Dan Leverage Pada Manajemen Laba Pada Emiten Perbankan di Bursa Efek Indonesia”, JRMB, 10 (1) Juni 2015

Satria Nugroho, (2015) Pengaruh Kompensasi, Kepemilikan Manajerial, Diversifikasi Perusahaan Dan Ukuran Kap Terhadap Manajemen Laba (studi empiris pada perusahaan manufaktur yang terdaftar di Bursa Efek Indonesia tahun 2011-2013), http://eprints.undip.ac.id/46188/1/02_NUGROHO.pdf

Sarwono, Jonathan, (2013) “12 Jurus Ampuh SPSS untuk Riset Skripsi”, Elexmedia Komputindo Kompas Gramedia, Jakarta.

Sulistyanto, Sri. (2006) Manajemen laba, teori dan Model empiris. 06. rasindo. Jakarta.

Sulistiawan, D., Januarsi, Y., \& Alvia, L. (2011) Creative accounting: mengungkap manajemen labadan skandal akuntansi. Jakarta: Salemba Empat

Sulistyanto, H. Sri. (2008) Manajemen Laba, Teori dan Model Empiris. Jakarta: Grasindo. Surat Edaran Bank Indonesia No. 9/12/DPNP tentang Corporate Governance di Perbankan. Surat Edaran Bank Indonesia No. 11/4/DPNP. www.bi.go.id. Diakses tanggal 10 Juli 2012

Sofian Riski Tsani, (2011) "Pengaruh kompensasi Bonus, Leverage, Praktik Corporate Governance terhadap Manajemen Laba pada Perusahaan Manufaktur di Indonesia yang Terdaftar di BEI th 2007 -2009”, Skripsi Universitas Sebelas Maret Surakarta

Suriana, (2013) "Pengaruh Struktur Kepemilikan, Ukuran Perusahaan dan afiliasi group bisnis terhadap Manajemen laba (studi empiris pada perusahaan manufaktur yang 
terdaftar di BEI Tahun 2008-2012)”, Jurnal Implementasi Ekonomi dan Bisnis FEUNIVA MEDAN

Suryabrata, Sumadi, (2003) Metodologi Penelitian. PT Raja Grafindo Persada,Jakarta

Toru Yoshikawa, Abdul A. Rasheed and Esther B. Del Brio, (2010) "The impact of firm strategy and foreign ownership on executive bonus compensation in Japanese firms", Journal of Business Research 63 (2010) 1254-1260, https://www.researchgate.net/profile/Toru_Yoshikawa2/publication/233740768_The _Impact_of_Firm_Strategy_and_Foreign_Ownership_on_Executive_Bonus_Compe nsation_in_Japanese_Firms/links/0c960528eecdf59ef0000000.pdf

Tri Kenyatyas Magdalena Puspa, (2014) “Pengaruh Diversifikasi Perusahaan, Kompensasi Bonus dan Profitabilitas terhadap Manajemen Laba (Studi kasus pada Perusahaan Consumer Goods di BEI Tahun 2012-2013)”, DISERTASI dan TESIS Program Pascasarjana UM, 2015, http://karyailmiah.um.ac.id/index.php/disertasi/article/view/41675

Titik Aryati, Yoel Charisma Walansendouw (2013) “Analisis Pengaruh Diversifikasi Perusahaan Terhadap Manajemen Laba”, Jurnal Jurnal Akuntansi \& Auditing, 9 (2): $244-260$

Tri Kenyatyas Magdalena Puspa, (2015) "Pengaruh Diversifikasi Perusahaan, Kompensasi Bonus dan Profitabilitas terhadap Manajemen Laba (Studi kasus pada Perusahaan Consumer Goods di BEI Tahun 2012-2013)”, http://karyailmiah.um.ac.id/index.php/disertasi/article/view/41675

Ulumiddin, Ahmad Ihya (2015) "Pengaruh Diversifikasi, Leverage dan Ukuran Perusahaan Terhadap Manajemen Laba (Studi Empiris pada Perusahaan Manufaktur yang Terdaftar di Bursa Efek Indonesia Tahun 2007 - 2011)”. Other Thesis, UPN"Veteran" Yogyakarta.

Vassiliki Grougiou, itc, (2013) Corporate Social Responsibility and Earnings Management in U.S. Banks, http://eprints.aston.ac.uk/25729/1/Corporate_social_responsibility_and_earnings_ma nagement_in_US_banks.pdf

Veronika Abdi Wijaya Dan Yulius Jogi Christiawan, (2014) "Pengaruh Kompensasi Bonus, Leverage, Dan Pajak Terhadap Earning Management Pada Perusahaan Yang Terdaftar Di Bursa Efek Indonesia Tahun 2009-2013”, Tax \& Accounting Review, 4 (1): 2014

Yasa, Gerianta Wirawan, (2010) "Peningkatan Obligasi Perdana sebagai Pemicu Manajemen Laba: Bukti Empiris dari Pasar Modal Indonesia”. Simposium Nasional Akuntansi (SNA) XIII, Purwokerto 